SAND94-1432

Unlimited Release

Printed May 1994
Distribution

Category UC- 813

\title{
Triaxial Creep Measurements on Rock Salt from the Jennings Dome, Louisiana, Borehole LA-1, Core \# ${ }^{*}$
}

\author{
W. R. Wawersik and D. J. Zimmerer \\ Geomechanics Department 6117 \\ Sandia National Laboratories \\ Albuquerque, NM 87185-0751
}

\begin{abstract}
Five creep experiments were performed on a rock salt sample from the depth of $3927.5 \mathrm{ft}$ $(1197.1 \mathrm{~m})$ in the Jennings dome, Acadia Parish, Louisiana. Measurements were conducted at principal stress differences, $\tau=\left(\sigma_{1}-\sigma_{3}\right)$, between 2300 psi and 2900 psi $(15.8-20.0 \mathrm{MPa}), 2000 \mathrm{psi}(13.8 \mathrm{MPa})$ confining pressure and nominally $40^{\circ} \mathrm{C}$ and $60^{\circ} \mathrm{C}$ $\left(104-140^{\circ} \mathrm{F}\right)$. Although individual test stages were not long enough to establish steady state creep, it became clear that this Jennings sample was unusually creep resistant. The data obtained did not suffice to determine the parameters for a power-law creep model that is frequently used for cavern design analyses. However, similarities between Jennings salt and some rock salt from the Bryan Mound dome may justify the use of Bryan Mound creep constant in preliminary calculations. Extraordinarily slow creep may be accompanied by material embrittlement and declining crack healing potential that may affect the long-term stability of Jennings salt under extensile stress states in the walls of storage caverns. It is emphasized that the results in this report are based on measurements on only one sample and are not necessarily typical for the response of the Jennings dome as a whole.
\end{abstract}

\footnotetext{
* This work was performed at Sandia National Laboratories, which is operated for the U.S. Department of Energy under contract number DE-AC04-94AL85000.
} 


\section{Contents}

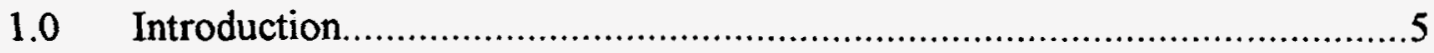

2.0 Test Matrix and Experimental Procedures.............................................5

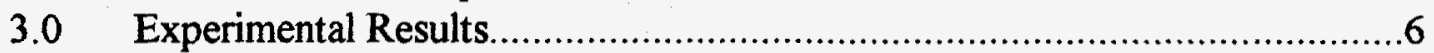

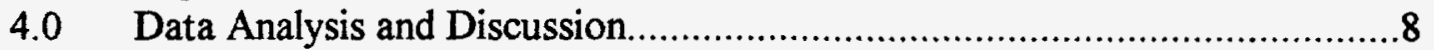

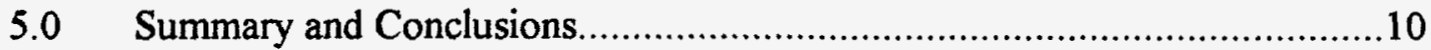

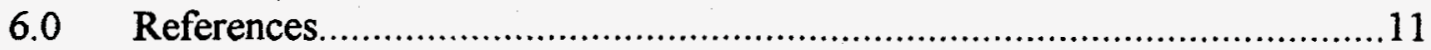

\section{Figures}

1 Stress histories for creep triaxial test on rock salt from Jennings dome, borehole LA-1, sample Tejas \#2, depth $3927.5 \mathrm{ft}(1197.1 \mathrm{~m})$. The indicated values of stress difference are the averages for each of five test stages.

2 Axial (most compressive) strain for triaxial creep test on rock salt from Jennings dome, borehole LA-1, sample Tejas \#2, depth $3927.5 \mathrm{ft}$ $(1197.1 \mathrm{~m})$. The strain rates shown represent linear least squares fits to the experimental data near the end of each five test stages

\section{Tables}

1 Stress and temperature conditions of creep tests on Jennings salt from Borehole LA-1, depth $3927.5 \mathrm{ft}$. 6

2 Average test conditions and creep measurements for Jennings salt sample Tejas \#2 from borehole LA-1, depth $3927.5 \mathrm{ft}$ .8

3 Comparisons of creep data for Jennings salt, borehole LA-1 with steady state creep estimates for rock salt from other sites. 


\section{DISCLAIMER}

This report was prepared as an account of work sponsored by an agency of the United States Government. Neither the United States Government nor any agency thereof, nor any of their employees, make any warranty, express or implied, or assumes any legal liability or responsibility for the accuracy, completeness, or usefulness of any information, apparatus, product, or process disclosed, or represents that its use would not infringe privately owned rights. Reference herein to any specific commercial product, process, or service by trade name, trademark, manufacturer, or otherwise does not necessarily constitute or imply its endorsement, recommendation, or favoring by the United States Government or any agency thereof. The views and opinions of authors expressed herein do not necessarily state or reflect those of the United States Government or any agency thereof. 


\section{DISCLAIMER}

Portions of this document may be illegible in electronic image products. Images are produced from the best available original document. 


\subsection{Introduction}

Tejas Power Company requested that facilities in the Rock Mechanics Laboratory at Sandia National Laboratories be used to assess the time-dependent properties of rock salt from the Jennings dome in Acadia Parish, Louisiana. Nominally 2.5-inch $(6.4 \mathrm{~cm})$ diameter salt core from borehole LA-1 , core 8 (depth 3924.8 to $3837.8 \mathrm{ft}$; 1196.8-1197.1 m) was provided to accomplish two tasks: (1) Using the smallest possible number of experiments, evaluate the tendency of Jennings salt to undergo time-dependent deformation (creep) under constant applied stresses, and compare the creep of Jennings salt with creep data for rock salt from other locations. (2) Assess the applicability of published laboratory-derived creep properties for rock salt from several bedded and domal sites in finite element analyses concerning the design of new gas storage caverns in the Jennings dome.

The characterization of Jennings salt followed the same strategy that was applied in earlier laboratory experiments on core from the Moss Bluff dome near Houston, Texas. This report summarizes the relevant details of five creep experiments on a sample from depth $3927.5 \mathrm{ft}(1197.1 \mathrm{~m})$, the results obtained, and how these results compare with laboratory creep measurements gathered on rock salt from other locations including the West Hackberry, Bryan Mound and Moss Bluff domes. The report also considers the estimates of specific creep parameters commonly used in numerical engineering design analyses.

\subsection{Test Matrix and Experimental Procedures}

Measurements were made in triaxial experiments at constant confining pressure of $\sigma_{3}=$ 2000 psi. Stress differences, $\tau=\left(\sigma_{1}-\sigma_{3}\right)$, were targeted to fall into the range 2300 (15.8 $\mathrm{MPa}) \leq \tau \leq 2900 \mathrm{psi}(20.0 \mathrm{MPa})$ and temperatures of nominally $40^{\circ} \mathrm{C}\left(104^{\circ} \mathrm{F}\right)$ and $60^{\circ} \mathrm{C}$ $\left(140^{\circ} \mathrm{F}\right)$. The exact stress and temperature conditions are listed in Table 1. Relatively large variations ( $\pm 30 \mathrm{psi} ; 0.2 \mathrm{MPa}$ ) in $\tau$ occurred during periods when the test temperature was changed to and from nominally $60^{\circ} \mathrm{C}\left(140^{\circ} \mathrm{F}\right)$. Other variations resulted from limited control of one component (axial load) of the testing system currently configured for use with sample diameters between 3.5 in and 4.0 in $(8.9-10.2 \mathrm{~cm})$. However, the observed stress variations were well within the bounds needed for the interpretation of the scoping experiments reported here.

All measurements were made on the same sample to eliminate sample-to-sample variations that might obscure the interpretation of creep measurements especially at very low strain rates. In addition, experiments involving step changes in stress and temperature often provide a means of bracketing the lowest possible or 'steady state' creep rates at any combination of the applied stress difference, $\tau$, and temperature, $T$. 
TABLE 1 - Stress and temperature conditions of creep tests on Jennings salt from borehole LA-1, depth $3927.5 \mathrm{ft}$

\begin{tabular}{cccc} 
Test Stage & $\begin{array}{c}\text { Confining Pressure } \\
\text { psi }(\mathrm{MPa})\end{array}$ & $\begin{array}{c}\text { Stress Difference } \\
\text { psi (MPa) }\end{array}$ & $\begin{array}{c}\text { Temper. } \\
{ }^{\circ} \mathrm{C}\end{array}$ \\
\hline 1 & $2000 \pm 2(13.8 \mathrm{MPa})$ & $2515_{-30}^{+33}(17.3)$ & 39.8 \\
2 & $2000 \pm 2$ & $2365_{-13}^{+8}(16.3)$ & 59.7 \\
3 & $2000 \pm 2$ & $2510_{-23}^{+17}(17.3)$ & 59.7 \\
4 & $2000 \pm 2$ & $2860_{-16}^{+18}(19.7)$ & 59.7 \\
5 & $2000 \pm 2$ & $2860_{-14}^{+5}(19.7)$ & 39.7 \\
\hline
\end{tabular}

Two samples were prepared from Jennings core centered at depths of $3926.5 \mathrm{ft}$ (1196.8 $\mathrm{m})$ and $3927.5 \mathrm{ft}(1197.1 \mathrm{~m})$. The samples were finished on a lathe to diameters of 2.48 in. $(6.3 \mathrm{~cm})$ and lengths of 5.9 in. $(15 \mathrm{~cm})$. The sample ends were machined flat and parallel to within 0.0005 in $(0.013 \mathrm{~mm})$. Only the sample from depth $3927.5(1197.1 \mathrm{~m})$ was used. It is referred to as Tejas $\# 2$ in this report and in all laboratory records because it is the second rock salt sample tested for Tejas Power Company. The first one was taken in the Moss Bluff dome (Wawersik, 1992).

The sample was enclosed in a thin flexible neoprene jacket to isolate the salt from the surrounding silicone fluid used as the confining pressure medium inside a pressure vessel. To minimize drilling- and machining-induced damage to the laboratory response of the salt, creep tests were started only after the sample had been seasoned for two days at 2000 psi hydrostatic pressure $(13.8 \mathrm{MPa})$ and $40^{\circ} \mathrm{C}\left(104^{\circ} \mathrm{F}\right)$ temperature. Stress differences were applied rapidly, i.e., stress changes were completed within 5 to 10 seconds. After 1870 hours ( 78 days) of combined hydrostatic and stress-difference testing, the sample was maintained under the hydrostatic pressure of $2000 \mathrm{psi}(13.8 \mathrm{MPa})$ until it had cooled to room temperature. At that point, the sample was completely unloaded and removed from the pressure vessel.

\subsection{Experimental Results}

The results of 1870 hours of creep testing are summarized in Figures 1 and 2 and in Table 2. The time derivative $\mathrm{de}_{1 \mathrm{~s}} / \mathrm{dt}$ denotes the creep rate at the end of each test stage as determined by a linear least squares fit. Ideally, the values $\mathrm{de}_{1 \mathrm{~s}} / \mathrm{dt}$ will also be good estimates of the steady state creep rates. The plot of stress difference versus time includes some electronically created spikes that had no influence on the sample response. The last creep stage in Figure 2 was caused by cooling from $59.7^{\circ} \mathrm{C}$ to $39.8^{\circ} \mathrm{C}\left(139.5-103.5^{\circ} \mathrm{F}\right)$. A similar offset between test stages 1 and 2 was removed by file editing. 


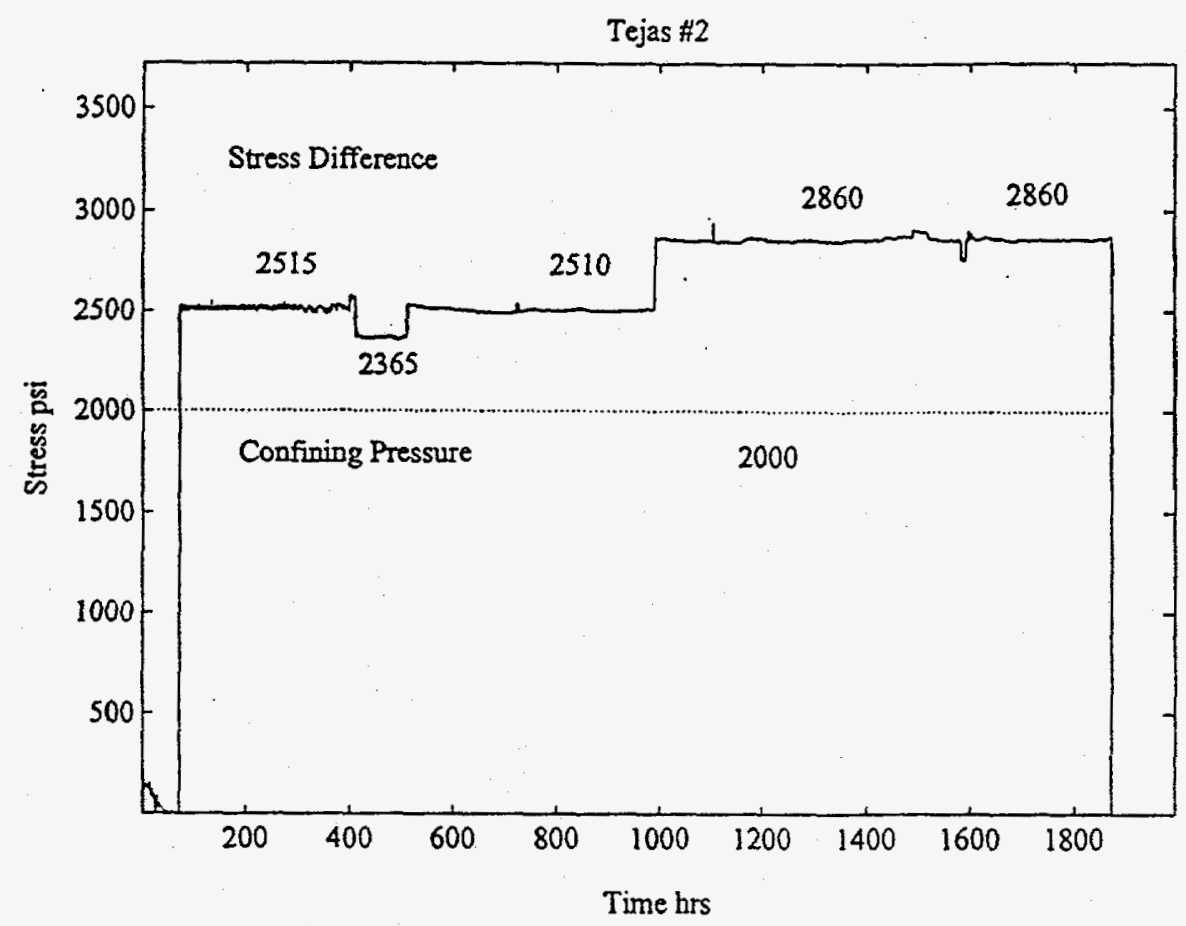

Figure 1 - Stress histories for creep triaxial test on rock salt from Jennings dome, borehole LA-1, sample Tejas \#2, depth $3927.5 \mathrm{ft}(1197.1 \mathrm{~m})$. The indicated values of stress difference are the averages for each of five test stages.

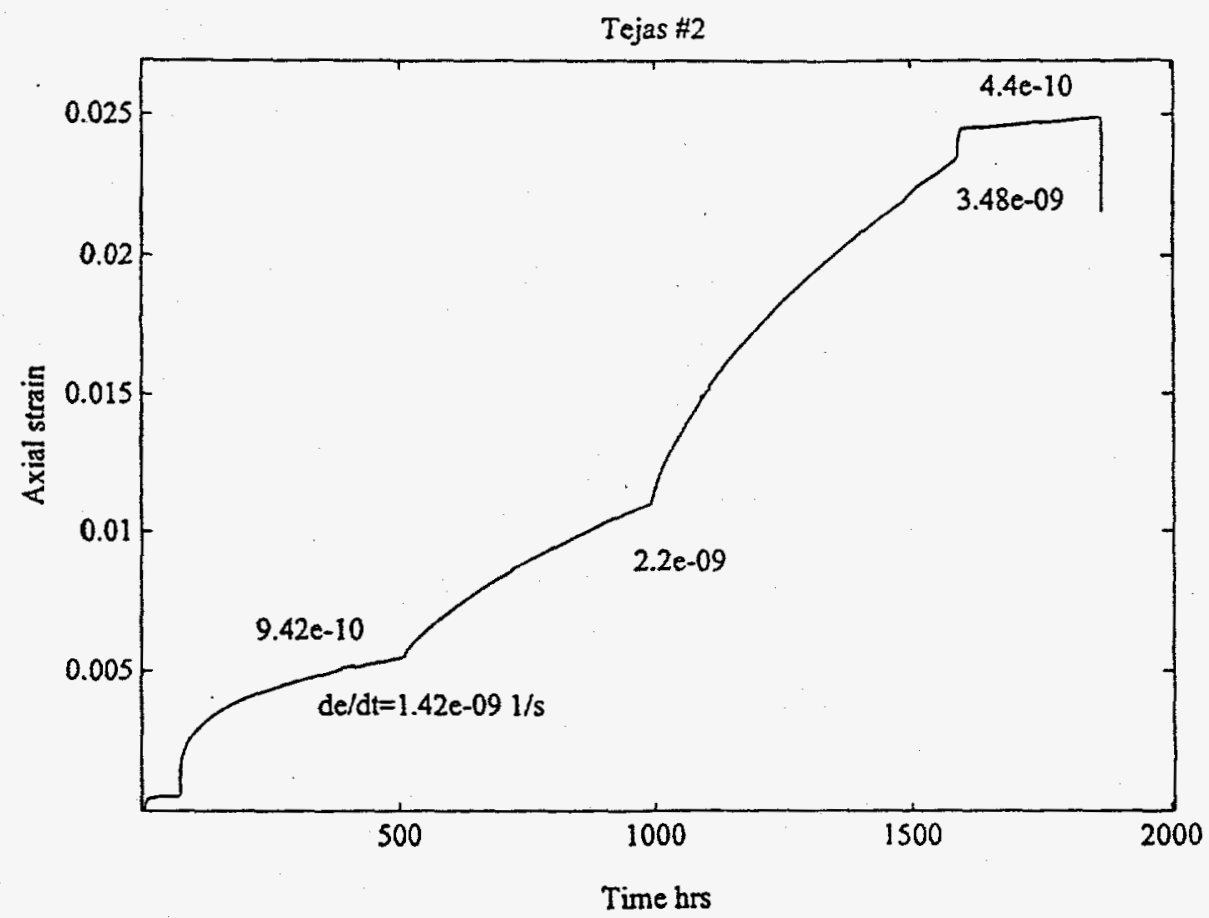

Figure 2 - Axial (most compressive) strain for triaxial creep test on rock salt from Jennings dome, borehole LA-1, sample Tejas \#2, depth $3927.5 \mathrm{ft}(1197.1 \mathrm{~m})$. The strain rates shown represent linear least squares fits to the experimental data near the end of each of five test stages. 
TABLE 2 - Average test conditions and creep measurements for Jennings salt sample Tejas \#2 from borehole LA-1, depth $3927.5 \mathrm{ft}$

\begin{tabular}{|c|c|c|c|c|c|c|}
\hline Test Stage & $\begin{array}{c}\text { Duration } \\
\text { hrs. } \\
\end{array}$ & $\begin{array}{c}\text { Avg. Conf. } \\
\text { Pressure } \\
\text { psi (MPa) }\end{array}$ & $\begin{array}{l}\text { Avg. Stress } \\
\text { Difference } \\
\text { psi (MPa) }\end{array}$ & $\begin{array}{c}\text { Temper. } \\
{ }^{\circ} \mathrm{C} \\
\end{array}$ & $\begin{array}{c}\Delta \mathrm{e}_{1} \\
\% \\
\end{array}$ & $\begin{array}{c}\mathrm{de}_{1 /} / \mathrm{dt} \\
\times 10^{-9} \\
1 / \mathrm{s} \\
\end{array}$ \\
\hline 1 & 330 & $2000(13.8)$ & $2515(17.3)$ & 39.8 & 0.49 & 1.42 \\
\hline 2 & 108 & $2000(13.8)$ & $2365(16.3)$ & 59.7 & 0.05 & 0.94 \\
\hline 3 & 485 & $2000(13.8)$ & $2510(17.3)$ & 59.7 & 0.55 & 2.20 \\
\hline 4. & 594 & $2000(13.8)$ & $2860(19.7)$ & 59.7 & 1.24 & 3.48 \\
\hline 5 & 269 & $2000(13.8)$ & $2860(19.7)$ & 39.7 & 0.06 & 0.44 \\
\hline
\end{tabular}

The shape of the strain-time records and the extraordinarily small accumulated creep strains $2.4 \%$ in Figure 2 and Table 2 indicate that the sample never reached steady state conditions with the associated steady-state creep rates, i.e., constant strain rates at fixed conditions of stress and temperature. However, using arguments described elsewhere (Wawersik, 1983, 1992), it is reasonable to assume that the true steady state creep rates will be lower than the strain rates at the end of tests involving decelerating creep. This condition normally arises after the stress or temperature have been increased (stages 1,3 and 4 in Table 2 and Figure 2). In turn, the true steady state creep rates will be larger than the measured rate at the end of tests exhibiting (slowly) accelerating creep following reductions in stress or temperature (test stage 5 and possibly 2 ).

\subsection{Data Analysis and Discussion}

In order to compare the results obtained for Jennings salt with rock salt data from other locations, recourse is taken to the most common model for steady state creep:

$$
\mathrm{de}_{1 \mathrm{~S}} / \mathrm{dt}=\mathrm{C} \exp (-\mathrm{Q} / \mathrm{RT})(\tau / \mathrm{G})^{\mathrm{n}}
$$

where $Q$ is an activation energy, $G$ is a typical elastic shear modulus for rock salt, $R=1.99$ $\mathrm{cal} / \mathrm{mole}$ is the universal gas constant, and $\mathrm{C}$ is a constant (structure factor). To apply the steady state creep equation, the following published parameter combinations of $Q$ (kcal/mole), $\mathrm{n}$, and $\mathrm{C}(1 / \mathrm{s})$ were used: $13.15(56.3 \mathrm{~kJ} / \mathrm{mole}), 4.73$, and $3.3 \mathrm{e} 14$ for West Hackberry; 15.17 (63.3 kJ/mole), 4.54, and 1.61el4 for the boreholes $107 \mathrm{C}$ and $108 \mathrm{~B}$ in the Bryan Mound dome; 12.03 ( $50.2 \mathrm{~kJ} / \mathrm{mole}), 4.9$, and $4.46 \mathrm{el} 4$ for bedded salt from the Waste Isolation Pilot Plant near Carlsbad, New Mexico; and 14.7 (61.3 kJ/mole), 5.0, and $9.94 \mathrm{e} 15$ for Moss Bluff. The Moss Bluff parameters are based on tests of limited duration on only one sample, and they were determined by methods almost identical to those used 
for characterizing Jennings salt in this account. Using $G=1.8 \mathrm{e} 6 \mathrm{psi}(12.4 \mathrm{GPa})$ the comparison Table 3 was obtained. Values in parentheses were normalized to the rates measured for Jennings salt.

\section{TABLE 3 - Comparisons of creep data for Jennings salt, borehole LA-1 with steady state creep estimates for rock salt from other sites.}

\begin{tabular}{|c|c|c|c|c|c|c|}
\hline \multirow{2}{*}{$\begin{array}{l}\text { Avg. Stress } \\
\text { Difference } \\
\text { psi (MPa) }\end{array}$} & \multirow{2}{*}{$\begin{array}{c}\text { Temper. } \\
{ }^{\circ} \mathrm{C} \\
\end{array}$} & \multicolumn{5}{|c|}{$\begin{array}{l}\text { Steady State Creep Estimates, } 1 / \mathbf{s} \\
\text { (normalized values) }\end{array}$} \\
\hline & & $\begin{array}{c}\text { West } \\
\text { Hackberry }\end{array}$ & $\begin{array}{l}\text { Bryan } \\
\text { Mound }\end{array}$ & WIPP & $\begin{array}{l}\text { Moss } \\
\text { Bluff } \\
\end{array}$ & Jennings \\
\hline 2515 & 39.8 & $\begin{array}{c}6.90 \mathrm{e}-9 \\
(>4.9)\end{array}$ & $\begin{array}{c}4.60 \mathrm{e}-10 \\
(>0.3)\end{array}$ & $\begin{array}{l}1.80 \mathrm{e}-8 \\
(>12.7)\end{array}$ & $\begin{array}{c}2.90 \mathrm{e}-9 \\
(>2.0)\end{array}$ & $\begin{array}{c}<1.42 \mathrm{e}-9 \\
(1.0)\end{array}$ \\
\hline 2510 & 59.7 & $\begin{array}{c}1.54 \mathrm{e}-8 \\
(>7.0)\end{array}$ & $\begin{array}{c}1.97 \mathrm{e}-9 \\
(>0.9)\end{array}$ & $\begin{array}{l}5.90 \mathrm{e}-8 \\
(>26.8)\end{array}$ & $\begin{array}{l}1.2 \mathrm{e}-8 \\
(>5.5)\end{array}$ & $\begin{array}{c}<2.2 \mathrm{e}-9 \\
(1.0)\end{array}$ \\
\hline 2860 & 39.7 & $\begin{array}{l}1.27 \mathrm{e}-8 \\
(<28.9)\end{array}$ & $\begin{array}{c}8.2 \mathrm{e}-10 \\
(<1.9)\end{array}$ & $\begin{array}{l}3.46 \mathrm{e}-8 \\
(<78.6)\end{array}$ & $\begin{array}{l}5.55 \mathrm{e}-9 \\
(<12.6)\end{array}$ & $\begin{array}{c}>4.4 \mathrm{e}-10 \\
(1.0)\end{array}$ \\
\hline 2860 & 59.7 & $\begin{array}{l}4.51 \mathrm{e}-8 \\
(>13.0)\end{array}$ & $\begin{array}{c}3.54 \mathrm{e}-9 \\
(>1.0)\end{array}$ & $\begin{array}{l}1.11 \mathrm{e}-7 \\
(>31.9)\end{array}$ & $\begin{array}{c}2.29 \mathrm{e}-8 \\
(>6.6)\end{array}$ & $\begin{array}{c}<3.48 \mathrm{e}-9 \\
(1.0)\end{array}$ \\
\hline 2365 & 59.7 & $\begin{array}{l}1.80 \mathrm{e}-8 \\
(>19.2)\end{array}$ & $\begin{array}{c}1.49 \mathrm{e}-9 \\
(>1.6)\end{array}$ & $\begin{array}{l}4.36 \mathrm{e}-8 \\
(>46.4)\end{array}$ & $\begin{array}{l}8.8 \mathrm{e}-9 \\
(>9.4)\end{array}$ & $\begin{array}{c}<9.4 \mathrm{e}-10 \\
(1.0)\end{array}$ \\
\hline
\end{tabular}

Efforts towards determining representative steady state creep parameters, Q, n, and C were largely unsuccessful because the creep rates at the end of each test stage appeared to be far from their steady state values. For example, the stress-change data of stages 2,3 and 3,4 in Table 2 yield 'power law' stress exponents $3.5 \leq n \leq 14.1$ consistent with the conclusions of other non-steady state measurements (Wawersik and Zeuch, 1986; Wawersik, 1992). Similarly, the measurements that are associated with a temperature change at constant stress, test stages 1,3 and 4,5 , lead to $4.5 \leq \mathrm{Q} \leq 21.5 \mathrm{kcal} / \mathrm{mole}(18.8 \leq \mathrm{Q}$ $\leq 89.7 \mathrm{~kJ} / \mathrm{mole})$. The high value of $21.5 \mathrm{kcal} / \mathrm{mole}(89.7 \mathrm{~kJ} / \mathrm{mole})$ is due to the fact that creep during stage 4 was still decelerating, i.e., the creep at the end of this phase of the experiment was greater than the true steady state creep rate under the prevailing conditions of stress and temperature. Additionally, the creep rate at the end of test stage 5 was less than the true steady state rate as indicated by an upward-curving, accelerating creep curve in Figure 2. Although both sets of values are considered to be valid bounds of the steady state parameters $Q$ and $n$, they are too far apart to calculate the structure factor $\mathrm{C}$ and, especially, make meaningful engineering predictions. As an alternative, it may be useful and acceptable to describe Jennings salt by means of the parameter combinations for Bryan Mound salt in Table 3. 
Apart from the difficulty in analyzing the Jennings data quantitatively, it is obvious that the particular core tested exhibited a greatly reduced tendency for creep compared with many if not most other rock salts. The same conclusion was drawn for the Bryan Mound samples that lead to the Bryan Mound data in Table 3. It should be recognized, however, that these particular measurements for Bryan Mound were only representative for sections of two borehole and not for another, nearby drillhole No. 113 in the same dome. Hence, Jennings salt may also creep faster at other depths and at other locations within the Jennings dome.

Reduced creep of rock salt around subsurface storage caverns implies a reduced loss in storage volume with time. It might appear, therefore, that the present cursory findings for Jennings salt are advantageous. This is true provided that higher creep resistance is not also accompanied by material embrittlement, i.e., increased tendency for microcrack formation and growth with declining crack healing potential. Although past experience in operating U.S. storage caverns in salt masses does not seem to indicate significant if any failure in the cavern walls, such potential for failure cannot be ruled over longer periods of time. Evaluations of possible salt fracture are deemed especially relevant around gas storage caverns subjected to frequent pressure cycling involving relatively large pressure changes. It is noted here that the present knowledge concerning failure of rock salt is inadequate to conduct definitive failure assessments under extensile stress conditions $\left(\sigma_{1}=\right.$ $\sigma_{2}>\sigma_{3}$ ) that are most representative for storage problems. Several independent measurements in different laboratories, however, have demonstrated the development of microfracturing and macroscopic extensile fracture at confining stresses as high as 2000 psi $(13.8 \mathrm{MPa})$. Moreover, the development of macroscopic fracture in extension occurred at much lower creep strains than the strains-to-failure typically measured in triaxial compression $\left(\sigma_{1}>\sigma_{2}=\sigma_{3}\right)$. In spite of these observations, current salt failure analyses appear to rely almost exclusively on failure measurement in compression.

\subsection{Summary and Conclusions}

Results were presented of five creep tests on a single piece of core from drillhole LA-1, depth 3927.5. The total test duration was 1900 hours (79 days) including the time needed for pre- and post-test sample conditioning. The results obtained were unusual because the accumulated creep strains of $2.4 \%$ and the associated creep rates (less than $3.5 \mathrm{e}-9 \mathrm{1} / \mathrm{s}$ throughout) were anomalously small and approximately ten times smaller than the creep rates recorded in laboratory experiments on salt from most other sites under the same conditions of stress difference, confining pressure and temperature. By comparison, Moss Bluff salt had undergone more than $13.5 \%$ shortening under nearly identical test conditions. The only rock salt with similar response was taken in one deep borehole in the Bryan Mound dome in Texas.

Because none of the creep rates measured had approached steady state conditions, it was not possible to determine meaningful creep parameters for use in cavern design calculations. Given the similarity between the Jennings sample described here and the 
Bryan Mound salt referred to above, it probably is reasonable to apply the rock salt creep constants for the Bryan Mound salt: $\mathrm{Q}=15.17 \mathrm{kcal} / \mathrm{mole}(63.3 \mathrm{~kJ} / \mathrm{mole}), \mathrm{n}=4.54$, and $\mathrm{C}=1.61 \mathrm{e} 14 \mathrm{1} / \mathrm{s}$. Based on observations at Bryan Mound, however, it is emphasized that rock salt from other sections of borehole LA-1 and from other parts of the Jennings dome may creep faster. It is also stressed that a higher creep resistance may be accompanied by material embrittlement, i.e., an increased tendency for microcrack formation and growth with declining crack healing potential. Such embrittlement may increase the macroscopic time-dependent fracture potential of rock salt. Additionally, it has been shown that salt fails at much smaller creep strains in extensile stress states which are most representative for the vicinity of storage caverns. In spite of this observation, current salt failure analyses appear to rely almost exclusively on failure measurements in compression.

\subsection{References}

Wawersik, W. R. and D. H. Zeuch, Modeling and mechanistic interpretation of creep of rock salt below $200^{\circ} \mathrm{C}$, Tectonophysics, 125-152, 1986 .

Wawersik, W. R., Determination of steady state creep rates an activation parameters for rock salt. In: High Pressure Testing of Rock, Special Technical Publication of ASTM, STP869, 72-91, 1983.

Wawersik, W. R., Indicator tests for the creep of rock salt from borehole Moss Bluff 2, Moss Bluff dome, Texas, report SAND92-2122, Sandia National Laboratories, Albuquerque, New Mexico, 1992. 


\section{External Distribution:}

Jack Gatewood (15)

Tejas Power Corporation

200 WestLake Park Boulevard

Suite 1000

Houston, TX 77079

Internal Distribution:

\begin{tabular}{|c|c|c|}
\hline MS & 0751 & W. R. Wawersik, 6117 \\
\hline 2 & 0751 & D. J. Zimmerer, 6117 \\
\hline 1 & 0751 & File, 6117 \\
\hline 1 & 9018 & Central Technical Files, $8523-2$ \\
\hline 5 & 0899 & Technical Library, 7141 \\
\hline 1 & 0619 & Technical Publications, 7151 \\
\hline 0 & 0100 & $\begin{array}{l}\text { Document Processing, } 7613-2 \\
\text { For DOE/OSTI }\end{array}$ \\
\hline
\end{tabular}

